EISSN: $2706-7947 \quad$ ISSN: $2077-4613$

DOI: 10.36632/mejas/2021.11.1.25

Journal homepage: www.curresweb.com

Pages: 313-322

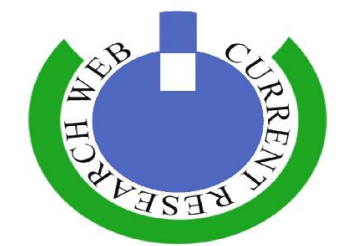

\title{
Effect of Bacterial Inoculants on Composition, Quality Characteristics, Bacterial Count and Nutritional Values of Date Palm Frond Silage
}

\author{
Hala M. A. Farrag' ${ }^{1}$ and M.M.El-Nahrawy ${ }^{2}$
}

${ }^{I}$ Central Laboratory of Date Palm for Researches and Development, (ARC) Giza, Egypt

${ }^{2}$ Animal Production Res. Institute, Agriculture. Res. Center, Ministry of Agric., Dokki, Giza, Egypt.

Received: 02 January $2021 \quad$ Accepted: 10 March $2021 \quad$ Published: 25 March 2021

\begin{abstract}
Three experimental silages were formulated from 59\% date palm leaves, $40 \%$ discarded date palm fruit and $1 \%$ Urea, then it was divided into three different parts. The first, control without inoculant; second, inoculated by Enterococcus faecium; third, inoculated by Lactobacillus plantarum and opened on 0, 7, 21,40 and 60 days of ensiling. Results showed that inoculated silages with E. faecium and L. plantarum were led to significant $(\mathrm{P}<0.05)$ in contents of $\mathrm{CP}, \mathrm{EE}, \mathrm{NFE}$ and $\mathrm{NFC}$ and significant $(\mathrm{P}<0.05)$ decrease in contents of $\mathrm{CF}, \mathrm{NDF}, \mathrm{ADF}, \mathrm{ADL}$, cellulose and hemicellulose compared to the control silage. The $\mathrm{pH}$ value of silage was lower significantly $(\mathrm{P}<0.05)$ with $E$. faecium and $L$. plantarum treated silage contrasted to control silage. Concentrations of lactic, acetic and propionic acids were significantly $(\mathrm{P}<0.05)$ the highest, however the concentrations of butyric acid and ammonia-N were significantly $(\mathrm{P}<0.05)$ the lowest in silage inoculated with $L$. plantarum followed by silage inoculated with $E$. faecium, however the lowest values were done in untreated control silage, The counts of E. faecium inoculant increased up to 21 days of ensiling and L. plantarum inoculant increased up to 40 days of ensiling and decreased afterwards. Counts of E. faecium strain was the highest at 21 days of ensiling, whereas, the highest counts of $L$. plantarum strain was at 40 days of ensiling. The counts of Enterococci and Lactobacillus increased significantly $(\mathrm{P}<0.05)$ in inoculated silages in comparison with uninoculated silage. Enterococci rich the highest counts at 21 days of ensiling in L. plantarum inoculated and at 40 days of ensiling in E. faecium inoculated silage. Meantime, the counts of Lactobacillus rich the highest counts at 7 days of ensiling in L. plantarum inoculated silages and at 21 days of ensiling in E. faecium inoculated silage. However, uninoculated silage recorded significantly $(\mathrm{P}<0.05)$ higher counts of Enterococci and Lactobacillus at 60 days of ensiling in compared to inoculated silages. Predicted dry matter intake (DMI) as a percentage of live body weight (LBW), dry matter digestibility (DMD), relative feeding value (RFV), relative forage quality (RFQ), digestible energy (DE) and total digestible nutrients $(\mathrm{TDN})$ were significantly $(\mathrm{P}<0.05)$ higher with $E$. faecium and L. plantarum inoculated silages compared to uninoculated control silage. However, gross energy (GE) did not affected significantly by bacterial inoculants.
\end{abstract}

Keywords: Date palm frond silage, bacterial inoculants, composition, fermentation, bacterial count, nutritional values.

\section{Introduction}

Ensiling is a preservation method for moist forage crops based on conversion of water-soluble carbohydrates into organic acids by lactic acid bacteria (LAB) under anaerobic conditions (McDonald et al., 1991). Silage can be defined as any plant material that has undergone fermentation or "pickling" in a silo. And a silo is any storage structure in which green, moist forage is preserved. The primary goal of making silage is to maximize the preservation of original nutrients in the forage crop for feeding of livestock at a later date in livestock feeding programs (Stewart, 2011). Inoculants are added to silage to dominate the epiphytic (natural) population of bacteria on plants that cause DM losses by inefficient fermentation of sugars. The three main types of microbial inoculants are 1) homofermentive; 2) 
homolactic; and 3) heterofermentive. Homofermentative inoculants contain bacteria such as Lactobacillus plantarum, Pediococcus and Lactococcus species. They promote a rapid fermentation producing mainly lactic acid and bring the $\mathrm{pH}$ down to 4 rapidly, preventing further breakdown of the sugar and protein in the crop. Heterofermentative inoculants-contain bacteria such as Lactobacillus buchneri and Lactobacillus brevis. They produce a mix of lactic and acetic acid which results in a slower fermentation than the homofermentative inoculants. They are designed to inhibit yeast and moulds that initiate the process of aerobic deterioration during feedout (Kenilworth and Warwickshire, 2012). Silage making process can be explained very simply, it is actually very complex and dependant on many factors, such as the natural microbial population, harvesting conditions and the sugar content of the forage. Consequently, silage quality can be very variable and the only way to effectively control the fermentation process is to use an additive. Additives are natural or industrial products added in rather large quantities to the forage or grain mass. Additives control or prevent certain types of fermentation, thus reducing losses and improving silage stability. In order to assist in the fermentation process, various silage additives have been used to improve the nutrient and energy recovery in silage, often with subsequent improvements in animal performance. The purpose for applying additives to the silage is to ensure that the growth of lactic bacteria predominates during the fermentation process, producing lactic acid in quantities high enough to ensure good silage. Therefore, this review is made to focus on some practical aspects of the fermentation process and the uses of some common silage additives that include microbial inoculants, enzymes, and propionic acid (Yitbarek and Tamir, 2014). The bacteria in the commercial products include one or more of the following species: Lactobacillus plantarum or other Lactobacillus species, various Pediococcus species and Enterococcus faecium (Muck and Kung, 1997). These strains of LAB have been isolated from silage and were selected because homofermentative specially Lactobacillus brevis has been reported as a promising strain for improving the aerobic stability of silage (Danner et al., 2003), they grow rapidly under a wide range of temperature and moisture conditions. Bacteria inoculants have inherent advantages over other additives, low cost, safety handling, a low application rate per ton of chopped crop and no residues or environmental problems. Palm frond is characterized as a feed with high content of cellulolytic components, low nutrients digestibility coefficients and high content of crude fiber such as cellulose and anti-nutrients factors such as tannins 87.7\% DM, 4.1\% CP, 72.4\% NDF, 52.3\%ADF and 14.6\% ADL (Abdel El Twab et al., 2016). The main aim of silage making is to conserve the plants with a minimum loss of nutritive value by fermentation of soluble carbohydrates in an anaerobic environment into organic acids, preferably lactic acid, which reduce $\mathrm{pH}$ (Saarisalo et al., 2007). Bacterial inoculants have advantage over chemical additives because they are easy to use, safe, the do not pollute environment and are regarded as natural products. The objective of this study was to investigate the effect of using of bacterial inoculants on the composition and quality of frond silage.

Objective of the current study was to investigate the effect of bacterial inoculants on composition, fermentation characteristics, bacterial counts and nutritional values of date palm frond silage.

\section{Material and Methods}

A trail was carried out in the Center Laboratory of Date Palm Research and Development, Agriculture Research Center, Giza, Egypt during the second half of 2020.

\subsection{Ensiled materials}

The date palm leaves were collected from the date palm tree and chopped by chopped machine to 2-5 cm length mixed with grinded discarded date 3-5 $\mathrm{mm}$ particular size. Urea was diluted in water and added to the ensiling mixture. Moisture content of the silage was adjusted by water to the normal moisture content of silage (65-70\%). The experimental silage was formulated from $59 \%$ date palm leaves, $40 \%$ discarded date palm fruit and $1 \%$ Urea.

\subsection{Making silage}

Silage ingredients were mixed during $15 \mathrm{~min}$, which were divided into three treatments each with 8 bags in each treatment as follows: (1) control without inoculant; (2) (LFM) inoculated by Enterococcus faecium; (3) inoculated by Lactobacillus plantrarum. The two strains Enterococus 
faecium and Lactobacillus plantarum were obtained from the culture collection of Microbiological Resource Center, Faculty of Agriculture, Ain Shams University. For ensiling experiments a fresh culture of each inoculant strain was diluted with Ringer solution to a population of $10^{9} \mathrm{CUF} / \mathrm{ml}$. the diluted culture was applied at $10 \mathrm{ml}$ per $\mathrm{kg}$ mixture.

Packed plastic bags $(30 \mathrm{~cm} \times 30 \mathrm{~cm})$ were closed to ensure anaerobic conditions and stored in a room temperature $\left(20-25^{\circ} \mathrm{C}\right)$ for 60 days. Representative samples of the raw material (control) mixture were taken for microbiological and chemical analyses before division. Three bags of each treatment were opened on $0,7,21,40$ and 60 days of ensiling for microbiological analyses and at 60 days for and chemical.

Table 1: Proximate analysis of ingredients used in silages

\begin{tabular}{lccc}
\hline Items & Date palm leaves & Discarded palm dates & Urea \\
\hline DM\% & 44.80 & 90.45 & 99.00 \\
\hline OM & \multicolumn{2}{c}{ Composition of DM\% } & 100.00 \\
CP & 93.19 & 90.35 & 288.00 \\
CF & 4.35 & 6.48 & \\
EE & 38.77 & 28.90 \\
NFE & 3.14 & 4.43 \\
Ash & 46.93 & 50.54 \\
& 6.81 & 9.65 \\
NDF & & Fiber fraction\% & \\
ADF & 74.10 & 55.70 \\
ADL & 51.70 & 36.80 \\
Cellulose & 18.26 & 8.90 \\
Hemicellulose & 33.50 & 27.90 \\
NFC* & 22.40 & 18.90 \\
\hline
\end{tabular}

Non fiber carbohydrates $(\mathrm{NFC}) *=[100-(\mathrm{NDF}+\mathrm{CP}+\mathrm{EE}+\mathrm{Ash})]$

DM (Dry matter), OM (Organic matter), CP (Crude protein), EE (Ether extract), NFE (Nitrogen free extract), CF (Crude fiber), ADF (Acid detergent fiber), NDF (Neutral detergent fiber) and ADL (Acid detergent lignin).

\subsection{Chemical analysis}

Samples of date palm leaves, discarded date palm fruit and silage were oven drying at $65{ }^{\circ} \mathrm{C}$ for 48 hours to determine DM content, then carried out to determine CP, CF, EE and Ash according to the methods of (AOAC, 1995). While, both OM and NFE were calculation by the differences. OM \% = $100-$ ash and NFE $\%=100-(\% \mathrm{EE}+\% \mathrm{CP}+\%$ Ash $+\% \mathrm{CF})$. As NFE values were calculated by the difference, all the errors associated with proximate analysis are additive in the estimate of NFE. Also, samples were analyzed for the contents of NDF, ADF and ADL were determined according to Van Soest et al. (1991) using Fibertec 2010 (Tecator Comp., Sweden).

\subsection{Evaluation of silage quality}

At the opening silage, $20 \mathrm{~g}$ of representative silage were mixed with $100 \mathrm{ml}$ sterile water in a laboratory blander (Waring, New Hartford, Conn, USA) for 2 min and the extract was filtered through four layers. The filter extract was used for determination silage quality including $\mathrm{pH}$, ammonia nitrogen, lactic acid and volatile fatty acids (VFA's). The $\mathrm{pH}$ of silage was determined immediately using HANNA pH meter (model HI 8424) and ammonia-N (AOAC, 1995). The total fatty acids were extracted from ensiled date palm frond based on the method of Folch et al. (1957) with some modifications by Rajion et al. (1985). The methylated fatty acids were separated by Agilent 7890A gas chromatography (Agilent Technologies) as described by Ebrahimi et al. (2013).

\subsection{Microbial enumeration}

For determining the counts of the inoculants as well as of the other enterococci and lactic acid bacteria, $10 \mathrm{~g}$ of ensiled mass was sampled and mixed with $90 \mathrm{ml}$ of Ringer solution $(\mathrm{pH} \mathrm{7.0,}$ Basingstoke, England); $100 \mathrm{ml}$ aliquots of serial dilutions were plated into the following media (in duplicate): M-Enterococcus agar to enumerate enterococci, MRS (De Man-Rogosa-Sharpe) agar to enumerate LAB (Becton and Dickinnson, Cockeysville, USA; Darmstadt, Germany). To differentiate E. faecium strain from the other enterococci, its rifampicin-marked variant was prepared by the subsequent cultivation of the strain using Todd-Hewitt agar (Becton and Dickinson) with rifampicin 
$(100 \mathrm{mg} / \mathrm{ml})$ at $37^{\circ} \mathrm{C}$ according to Strompfova (2004). To differentiate L. plantarum among the counts of lactic acid producing bacteria the strains were also marked by rifampicin. Bacterial counts were expressed in colony forming units $(\log 10 \mathrm{CFU})$ per $\mathrm{ml}$ per $\mathrm{g}$.

Microbial counts were determined using silage extractions (first dilution), which were continued into several dilutions $\left(10^{-5}-10^{-7}\right)$. The injection of silage extraction was in triplicate in selective agar medium as described by Kim et al. (2017) and Joo et al. (2018). The LAB count used lactobacilli MRS agar media (MRS; Difco, Detroit, MI, USA) and yeast and mold counts used potato dextrose agar (PDA; Difco, Detroit, MI, USA). The MRS agar plates were put on a CO2 incubator (Thermo Scientific, Waltham, MA, USA) at $30^{\circ} \mathrm{C}$ for $24 \mathrm{~h}$, while PDA plates were put on an aerobic incubator at $30^{\circ} \mathrm{C}$ for $72 \mathrm{~h}$ in an aerobic incubator (Johnsam Corp., Boocheon, South Korea). Visible colonies from the plates were calculated and the number of colonies forming units (cfu) was per gram of silage. The microbiological data was transformed to $\log 10$.

\subsection{Nutritional evaluation}

Dry matter intake (DMI), dry matter digestibility (DMD), relative feed value (RFV) and relative forage quality (RFQ) were determined according to Jeranyama and Garcia (2004). Also, calculated total digestible nutrients value (TDN) according to Horrocks and Vallentine (1999) as follows:

- DMI \% of LBW $=120 / \mathrm{NDF} \%$

- $\mathrm{DMD} \%=88.9-(0.779 \times \mathrm{ADF} \%)$

$-\mathrm{RFV} \%=(\mathrm{DMD} \times \mathrm{DMI}) / 1.29$

- RFQ \% $=(\mathrm{DMI}, \%$ of BW $) *(\mathrm{TDN}, \%$ of DM $) / 1.23$

- $\mathrm{GE} \mathrm{Mcal} / \mathrm{kg} \mathrm{DM}=[(0.226 \times(\% \mathrm{CP})+0.177 \times(\% \mathrm{CF})+0.407 \times(\% \mathrm{EE})+0.192 \times(\% \mathrm{NFE})] / 4.184$ (NRC, 2007).

- DE Mcal $/ \mathrm{kg} \mathrm{DM})=[2118+12.18 \times(\% \mathrm{CP})-9.37 \times(\% \mathrm{ADF})-3.83 \times(\%$ hemicellulose $)+47.18$ $\mathrm{x}(\% \mathrm{EE})+20.35 \mathrm{x}(\% \mathrm{NFC})-26.3 \mathrm{x}(\% \mathrm{ash})] / 1000(\mathrm{NRC}, 2007)$.

$-\mathrm{TDN}(\%)=(-1.291 \times \mathrm{ADF})+101.35$

\subsection{Statistical analysis}

The obtained data was subjected to statistical analysis using general linear model (GLM) procedure adapted by IBM SPSS Statistics (2020) for user's guide with one-way ANOVA. Duncan test within program SPSS was done to decide the degree of significance between the means (Duncan, 1955).

\section{Results and Discussion}

\subsection{Silage composition}

The effect of microbial inoculants on chemical composition of different date palm frond silages are shown in Table (2). Inoculants of E. faecium and L. plantarum revealed significant $(\mathrm{P}<0.05)$ improvements in chemical composition and cell wall constituents of date palm frond silage in compared to control silage. Inoculated silages with $E$. faecium and L. plantarum were led to significant $(\mathrm{P}<0.05)$ in contents of CP, EE, NFE and NFC and significant $(\mathrm{P}<0.05)$ decrease in contents of CF, NDF, ADF, $\mathrm{ADL}$, cellulose and hemicellulose compared to the control silage. Inoculated silage with E. faecium and L. plantarum increased CP, EE, NFE and NFC by 20.26, 18.56\%; 5.97, 3.69; 7.31, 8.40 and 15.37, $21.50 \%$, compared to control silage, respectively. The lower contents of cellulose and hemicellulose for the inoculated silages refer to the biological treatments decreased CF content and cell wall constituents (NDF, ADF and ADL). Treated silages were lower in the contents of CF, NDF, ADF, ADL, cellulose and hemicellulose by $14.90,15.84 ; 6.00,6.96 ; 5.36,6.52 ; 4.54,5.46 ; 6.75,7.02$ and $7.37,7.90 \%$ for $E$. faecium and L. plantarum compared to control silage, respectively. This decrease probably due to breakdown of gross linkage between lignin and cell wall component and solubilizing of cell wall contents (mainly hemicellulose). The best $(\mathrm{P}<0.05)$ product recovery was for $L$. plantarum, followed by $E$. faecium while the lower $(\mathrm{P}<0.05)$ product recovery was for control. Further results showed that fat content was higher with E. faecium inoculant than that of control and L. plantarum inoculanted silages. These results are in agreement with those obtained by Elmenofy et al. (2011) who found that chemical composition of the different rice straw silage treatments showed that CP, EE and NFE increased significantly $(\mathrm{P}<0.05)$, while $\mathrm{CF}$ content decreased significantly $(\mathrm{P}<0.05)$ with bacterial 
inoculants. The $\mathrm{LAB}+\mathrm{CB}$ treatment with molasses showed significantly $(\mathrm{P}<0.05) \mathrm{DM}, \mathrm{CP}$ and NFE and significantly decreased $(\mathrm{P}<0.05) \mathrm{CF}$. Arriola et al. (2011) stated relatively low NDF and ADF concentrations in silage with bacterial inoculants such as Biotal Plus II containing Pediococcus pentosaceus and Propionibacteria freudenreichii or Buchneri 40788 (BUC) containing Lactobacillus buchneri; or Buchneri 500 (B500) containing Pediococcus pentosaceus and L. buchneri., which is probably attributable to the action of the fibrolytic enzymes. Compared to the control, crude fibre content as well as detergent fiber (ADF) was significantly or numerically (NDF) lower in all inoculated silages (Jalč et al., 2009). Ebrahimi et al. (2014) reported an increase of $12 \%$ of the CP content was observed in the ensiled oil palm frond with additives is most likely related to the observed decrease of the NDF and to a lesser extent of the EE content of the silages. Clearly, the loss of NDF and EE increases the relative proportion of CP, expressed in $\mathrm{g} / \mathrm{kg} \mathrm{DM}$. Zahiroddini et al. (2004) and Bureenok et al. (2012) observed an increase in the CP content of silages from whole-crop barley and Napier grass, respectively.

Table 2: Proximate chemical composition of different silages at 60 days.

\begin{tabular}{lcccc}
\hline \multicolumn{1}{c}{ Items } & Control & E. faecium & L. plantarum & SEM \\
\hline DM \% & 34.60 & 34.17 & 34.28 & 0.19 \\
\hline & & Composition of DM \% & \\
OM & 90.60 & 90.90 & 90.80 & 0.53 \\
CP & $10.02^{\mathrm{b}}$ & $12.05^{\mathrm{a}}$ & $11.88^{\mathrm{a}}$ & 0.33 \\
CF & $34.10^{\mathrm{a}}$ & $29.02^{\mathrm{b}}$ & $28.70^{\mathrm{c}}$ & 0.83 \\
EE & $3.52^{\mathrm{b}}$ & $3.73^{\mathrm{a}}$ & $3.65^{\mathrm{a}}$ & 0.05 \\
NFE & $42.96^{\mathrm{b}}$ & $46.10^{\mathrm{a}}$ & $46.57^{\mathrm{a}}$ & 0.61 \\
Ash & 9.40 & 9.10 & 9.20 & 0.07 \\
\hline & \multicolumn{3}{c}{} \\
NDF & $64.50^{\mathrm{a}}$ & Fiber fractions \% & $60.01^{\mathrm{b}}$ & 0.79 \\
ADF & $63.87^{\mathrm{a}}$ & $41.52^{\mathrm{b}}$ & $41.01^{\mathrm{b}}$ & 0.50 \\
ADL & $14.09^{\mathrm{a}}$ & $13.45^{\mathrm{b}}$ & $13.32^{\mathrm{b}}$ & 0.11 \\
Cellulose & $29.78^{\mathrm{a}}$ & $27.77^{\mathrm{b}}$ & $27.69^{\mathrm{b}}$ & 0.46 \\
Hemicellulose & $20.63^{\mathrm{a}}$ & $19.11^{\mathrm{b}}$ & $19.00^{\mathrm{b}}$ & 0.29 \\
NFC & $12.56^{\mathrm{b}}$ & $14.49^{\mathrm{a}}$ & $15.26^{\mathrm{a}}$ & 0.56 \\
\hline
\end{tabular}

a, b, c: Values in the same row with different superscripts differ at $5 \%$ level.

\subsection{Silage quality}

Parameters such as silage $\mathrm{pH}$, short chain fatty acids and ammonia content are commonly used as indicators of silage quality. The inoculation of ensiled date palm frond influenced the fermentation parameters of silage as shown in Table (3). The $\mathrm{pH}$ value of silage was lower significantly $(\mathrm{P}<0.05)$ with E. faecium and L. plantarum treated silage in compared with control silage. The $\mathrm{pH}$ value of inoculated and uninoculated silages after 60 days of ensiling tended to be lower 4.5. It is generally accepted that in well preserved silages, $\mathrm{pH}$ values should be $<4.5$ (McDonald et al., 1991). Lactic acids and other organic acids i.e. acetic, propionic and butyric acids are usually responsible for the largest part of the drop silage $\mathrm{pH}$ (Shaver, 2003). Concentrations of lactic, acetic and propionic acids were significantly $(\mathrm{P}<0.05)$ the highest in silage inoculated with $L$. plantarum followed by silage inoculated with $E$. faecium, however the lowest values were done in untreated control silage (Table 3 ). Lactic acid concentrations constitute $61.42,65.45$ and $69.16 \%$ of total acids for untreated or treated with E. faecium and L. plantarum silages, respectively. Lactic acid should account for at least $65-70 \%$ of the total acids in good silage (Shaver, 2003). Opposite trend was observed in the concentrations of butyric acid and ammonia-N, which were significantly $(\mathrm{P}<0.05)$ the lowest with L. plantarum inoculant silage followed by E. faecium inoculant silage, but the highest values were with uninoculant control silage. These results are in agreement with those obtained by Elmenofy et al. (2011) who found that LAB and CB with molasses supplementation to fresh green rice straw showed significantly $(\mathrm{P}<0.05)$ the highest lactic acid and TVFA's concentrations and also the higher percentages of lactic, acetic and propionic acids and the lower $\mathrm{pH}$ value, $\mathrm{NH}_{3}-\mathrm{N}$ concentration and the percentages of iso-butyric and butyric acids. Ammonia$\mathrm{N}$ levels of good quality silage should be $<10 \%$ of total nitrogen (McDonald et al., 1991). The highest lactic acid content was found in the oil palm frond silage treated with both LAB and cellulase. The increase in the lactic acid was associated with a decrease of the $\mathrm{pH}$ and the lowest $\mathrm{pH}$ values were found 
in the silages treated with additives. The highest concentrations of acetic and butyric acids and that of $\mathrm{NH}_{3}-\mathrm{N}$ were found in the oil palm frond silage without additives (Ebrahimi et al., 2014). Overall, microbial inoculants generally had a positive effect on orchard grass silage characteristics in terms of lower $\mathrm{pH}$ and higher lactic acid concentration. The total concentration of acids (acetic, propionic, butyric, lactic acid) was 2-3 times higher in inoculated silages compared to control silage (Jalč et al., 2009). Inoculated maize and lucerne silages had greater level of lactic and acetic acids $(\mathrm{P}<0.01)$ as well as reduced $\mathrm{pH}$ value $(\mathrm{P}<0.01)$ than not inoculated ones (Stoškus et al., 2019). Zhang et al. (2009) and Sánchez et al. (2014) concluded that the inoculated alfalfa silage had more lactic acid and acetic acid content than the control. Many studies have indicated that acetic acid has anti-fungal properties, reduces aerobic spoilage of silage and growth of moulds and yeasts (McDonald et al., 1991; Schmidt et al., 2009; Čabarkapa et al., 2010a, b). Otherwise acetic acid is produced naturally during fermentation, with or without inoculants. Seglar (2003) reported that the presence of butyric acid is the result of Clostridial activity. Clostridia spores degrade lactic acid to butyric acid. Pahlow et al. (2003) concluded that to prevent Clostridial activity should be reached lower $\mathrm{pH}$ value, which was achieved in the treated silage with Silko.

Table 3: Fermentation characteristics of different silages at 60 days.

\begin{tabular}{lcccc}
\hline \multicolumn{1}{c}{ Items } & Control & E. faecium & L. plantarum & SEM \\
\hline pH & $4.41^{\mathrm{a}}$ & $4.13^{\mathrm{b}}$ & $4.05^{\mathrm{b}}$ & 0.06 \\
Lactic acid \% of DM & $4.25^{\mathrm{c}}$ & $6.08^{\mathrm{b}}$ & $8.52^{\mathrm{a}}$ & 0.65 \\
Acetic acid \% of DM & $1.53^{\mathrm{ac}}$ & $1.92^{\mathrm{b}}$ & $2.35^{\mathrm{a}}$ & 0.14 \\
Propionic acid \% of DM & $0.41^{\mathrm{c}}$ & $0.76^{\mathrm{b}}$ & $1.10^{\mathrm{a}}$ & 0.59 \\
Butyric acid \% of DM & $0.73^{\mathrm{a}}$ & $0.53^{\mathrm{b}}$ & $0.35^{\mathrm{c}}$ & 0.04 \\
Ammonia-N \% of total-N & $6.02^{\mathrm{a}}$ & $4.85^{\mathrm{b}}$ & $3.94^{\mathrm{c}}$ & 0.40 \\
\hline
\end{tabular}

a,b,c: Values in the same row with different superscripts differ at 5\% level.

\subsection{Bacterial count}

The inoculants bacteria were established sufficiently during ensiling (Table 4). The counts of $E$. faecium inoculant increased up to 21 days of ensiling and L. plantarum inoculant increased up to 40 days of ensiling and decreased afterwards. Counts of E. faecium strain amounted to $9.22 \log 10 \mathrm{CFU} / \mathrm{g}$ at 21 days of ensiling, whereas, the highest counts of L. plantarum strain amounted to $8.41 \log 10 \mathrm{CFU} / \mathrm{g}$ at 40 days of ensiling, but all inoculants were still determined in sufficient amount in the silage. The counts of Enterococci and Lactobacillus increased significantly $(\mathrm{P}<0.05)$ in E. faecium and L. plantarum inoculated silages in comparison with uninoculated control silage. Enterococci rich the highest counts at 21 days of ensiling in L. plantarum inoculated silages being $10.12 \log 10 \mathrm{cfu} / \mathrm{g}$ and at 40 days of ensiling in E. faecium inoculated silage being $9.71 \log 10 \mathrm{cfu} / \mathrm{g}$. Meantime, the counts of Lactobacillus rich the highest counts at 7 days of ensiling in L. plantarum inoculated silages being $8.66 \log 10 \mathrm{cfu} / \mathrm{g}$ and at 21 days of ensiling in E. faecium inoculated silage being $9.98 \log 10 \mathrm{cfu} / \mathrm{g}$. However, uninoculated control silage recorded significantly $(\mathrm{P}<0.05)$ higher counts of Enterococci and Lactobacillus at 60 days of ensiling in compared to E. faecium and L. plantarum inoculated silages (6.38, 8.77 vs 4.81, 5.87 and $5.67,5.59 \log 10 \mathrm{cfu} / \mathrm{g}$, respectively). These results are in agreement with findings of Marcinakova et al. (2008) reported for silage $9.15 \log 10 \mathrm{CFU} / \mathrm{g}$ of the probiotic strain of E. faecium EF9296 isolate from silage, (Marcinakova et al., 2004) used as inoculant for grass silage. To compare the counts of enterococci and LAB on day 7 with their counts in control silage, the inoculation with E. faecium increased their counts significantly $(\mathrm{P}<0.05)$. The same situation was found in the silage with $\mathrm{L}$. plantrum strain concerning the count of LAB (Table 4). This ratio was then slightly changed because it was probably influenced by the organic acid concentration in the competitive relations although the inoculants accounted for a predominant portion of the total enterococci or lactic acid bacteria. As for $\mathrm{pH}$, it was similar in the inoculate silages as well as in the control silage. Ebrahimi et al. (2014) found that the LAB count was raised after 12 weeks of ensiling in all experimental silages but the LAB counts were only significantly higher in the silages treated with additives (Table 1). The rise in LAB count was associated with a significant decrease of the WSC content and a concomitant increase of the lactic acid content of the silages. Amanullah et al. (2014) reported that lactic acid bacteria were observed higher in LP and EM silages than in the control silage $(\mathrm{P}<0.05)$, which was directly due to the bacterial inoculation. Khota et al (2017) stated that LAB counts significantly increased in the silages compared 
to fresh sorghum. The most plausible explanation lies in the physiological properties of LAB and the chemical composition in sorghum that contained a high level of WSC (35.5\% DM) for LAB to produce higher lactic acid. Some tropical isolates were homofermentative $\mathrm{LAB}$ which could grow well $<\mathrm{pH} 4.0$ in silage (Pholsen et al., 2016).

Table 4: Counts of inoculant, Enterococci and Lactobacillus bacteria in different silages at different ensiling period.

\begin{tabular}{|c|c|c|c|c|}
\hline Silage & Control & E. faecium & L. plantarum & SEM \\
\hline \multicolumn{5}{|c|}{ Day 0 } \\
\hline Inoculants & $\mathrm{Nd}$ & 7.00 & 7.00 & 0.05 \\
\hline Enterococci & $1.15^{\mathrm{b}}$ & $1.30^{\mathrm{b}}$ & $2.20^{\mathrm{a}}$ & 0.16 \\
\hline Lactobacillus & $1.41^{\mathrm{b}}$ & $1.41^{\mathrm{b}}$ & $1.88^{\mathrm{a}}$ & 0.08 \\
\hline \multicolumn{5}{|c|}{ Day 7} \\
\hline Inoculants & $\mathrm{Nd}$ & 8.20 & 7.45 & 0.08 \\
\hline Enterococci & $6.38^{\mathrm{c}}$ & $8.31^{\mathrm{a}}$ & $7.20^{\mathrm{b}}$ & 0.28 \\
\hline Lactobacillus & $6.21^{\mathrm{b}}$ & $8.36^{\mathrm{a}}$ & $8.66^{\mathrm{a}}$ & 0.39 \\
\hline \multicolumn{5}{|c|}{ Day 21} \\
\hline Inoculants & $\mathrm{Nd}$ & 9.22 & 7.55 & 0.40 \\
\hline Enterococci & $8.01^{\mathrm{b}}$ & $9.42^{\mathrm{a}}$ & $10.12^{\mathrm{a}}$ & 0.31 \\
\hline Lactobacillus & $8.43^{\mathrm{b}}$ & $9.98^{\mathrm{a}}$ & $8.41^{\mathrm{b}}$ & 0.27 \\
\hline \multicolumn{5}{|c|}{ Day 40} \\
\hline Inoculants & $\mathrm{Nd}$ & 7.67 & 8.41 & 0.06 \\
\hline Enterococci & $7.88^{\mathrm{b}}$ & $9.71^{\mathrm{a}}$ & $7.55^{\mathrm{a}}$ & 0.59 \\
\hline Lactobacillus & $6.53^{\mathrm{b}}$ & $8.27^{\mathrm{a}}$ & $7.11^{\mathrm{b}}$ & 0.39 \\
\hline \multicolumn{5}{|c|}{ Day60 } \\
\hline Inoculants & $\mathrm{Nd}$ & 3.20 & 6.43 & 0.72 \\
\hline Enterococci & $6.38^{\mathrm{a}}$ & $4.81^{\mathrm{c}}$ & $5.67^{\mathrm{b}}$ & 0.40 \\
\hline Lactobacillus & $8.77^{\mathrm{a}}$ & $5.87^{\mathrm{b}}$ & $5.59^{\mathrm{b}}$ & 0.42 \\
\hline
\end{tabular}

a,b,c: Values in the same row with different superscripts differ at $5 \%$ level.

\subsection{Nutritional evaluation}

Nutritional evaluation of different inoculated date palm frond silages is presented in Table (5). Predicted dry matter intake (DMI) as a percentage of live body weight (LBW) increased significantly $(\mathrm{P}<0.05)$ with $E$. faecium and L. plantarum inoculated silages compared to uninoculated control silage being 1.98 and 2.00 vs $1.86 \%$ of LBW, respectively. This result indicated that bacterial inoculants enhanced the palatability of date palm frond silage.

Table 5: Nutritional evaluation of different inoculated silages.

\begin{tabular}{lcccc}
\hline Items & Control & E. faecium & L. plantarum & SEM \\
\hline DMI \% of LBW & $1.86^{\mathrm{b}}$ & $1.98^{\mathrm{a}}$ & $2.00^{\mathrm{a}}$ & 0.02 \\
DMD \% & $54.73^{\mathrm{b}}$ & $56.56^{\mathrm{a}}$ & $56.95^{\mathrm{a}}$ & 0.39 \\
RFV \% & $78.96^{\mathrm{b}}$ & $86.81^{\mathrm{a}}$ & $88.32^{\mathrm{a}}$ & 1.65 \\
RFQ \% & $66.05^{\mathrm{b}}$ & $73.53^{\mathrm{a}}$ & $75.30^{\mathrm{a}}$ & 1.61 \\
GE Mcal/kg DM & 4.30 & 4.35 & 4.33 & 0.03 \\
DE Mcal/kg DM & $1.92^{\mathrm{b}}$ & $2.01^{\mathrm{a}}$ & $2.04^{\mathrm{a}}$ & 0.02 \\
TDN \% & $44.71^{\mathrm{b}}$ & $47.75^{\mathrm{a}}$ & $48.41^{\mathrm{a}}$ & 0.65 \\
\hline
\end{tabular}

a,b: Values in the same row with different superscripts differ at $5 \%$ level.

Likewise, dry matter digestibility (DMD), relative feeding value (RFV), relative forage quality (RFQ), digestible energy (DE) and total digestible nutrients $(\mathrm{TDN})$ were significantly $(\mathrm{P}<0.05)$ higher with $E$. faecium and L. plantarum inoculated silages compared to uninoculated control silage. Inoculated date palm frond silage with E. faecium and L. plantarum led significant $(\mathrm{P}<0,05)$ increase in by 3.34 and $4.06 \%$ for DMD, 9.94 and $11.85 \%$ for RFV, 11.31 and $14.00 \%$ for RFQ, 4.69 and $6.25 \%$ for DE and 6.80 and $8.26 \%$ for TDN, respectively. Whereas, gross energy (GE) did not significantly affected by bacterial inoculants. TDN is directly related to digestible energy and is often calculated based on ADF. Higher TDN and RFV values indicate higher forage quality. They are indication of good chemical composition of treated silage. These results are in accordance with those obtained by Đorđević et al. 
(2016) who found that total digestible nutrients value (TDN) and relative feed value (RFV) have significant higher in alfalfa silage treated with bacterial inoculant than control. Aragon et al. (2012) reported that the digestible energy content was highly significant in the treated silage compared to the untreated silage. It appeared that the in vitro digestibility of OPF ensiled with cellulase was at least $6.9 \%$ greater than the silage without additives (Ebrahimi et al., 2014).

\section{Conclusions}

The microbial inoculants generally had a positive effect on date palm frond silage characteristics in terms of chemical composition, fermentation quality, microbial counts and nutritional values.

\section{References}

Abdel El Tawab, A.M., M.S.A. Khattab, H.M. El-Zaiat, O.H. Matloup and A.A. Hassan, 2016. Effect of cellulose and tannase enzymes supplementation on the productive performance of lactating buffaloes fed diets contain date palm fronds. Asian-Australasian Journal of Animal Sciences, 10: 307-312.

Amanullah, S.M., D.H. Kim, H.J. Lee, Y.H. Joo, S.B. Kim and S.C. Kim, 2014. Effects of microbial additives on chemical composition and fermentation characteristics of barley silage. AsianAustralasian J. Anim. Sci., 27(4): 511-517.

AOAC, 1995. Official Methods of Analysis. Vol. I. 16th ed. Association of Official Analytical Chemists, Washington, DC.

Aragon, Y.A., J. Jatkauskas and V. Vrotniakiene, 2012. The Effect of a Silage Inoculant on Silage Quality, Aerobic Stability, and Meat Production on Farm Scale. International Scholarly Research Network, Volume 2012, Article ID 345927, 6 pages.

Arriola, K.G., S.C. Kim, C.R. Staples and A.T. Adesogan, 2011. Effect of applying bacterial inoculants containing different types of bacteria to corn silage on the performance of dairy cattle. J. Dairy Sci., 94: 3973-3979.

Bureenok, S., C. Yuangklang, K. Vasupen, J.T. Schonewille and Y. Kawamoto, 2012. The effects of additives in Napier grass silages on chemical composition, feed intake, nutrient digestibility and rumen fermentation, Asian-Australasian Journal of Animal Sciences, 25: 1248-54.

Čabarkapa, I., D. Palić, D. Plavšić and D. Jeremić, 2010a. The influence of a bacterial inoculant on reduction of aerobic microflora during ensiling of alfalfa. The Book of abstracts of the 9th International symposium of animal biology and nutrition, Bucharest, Romania, 23-24 September, 38-39.

Čabarkapa, I., D. Palić, D. Plavšić, Đ. Vukmirović and R. Čolović, 2010b. The influence of a bacterial inoculant on reduction of aerobic microflora during ensiling of alfalfa. Food and Feed Research, 1: 23-26.

Danner, H., M. Holzer, E. Mayrhuber and R. Braun, 2003. Acetic acid increases stability of silage under aerobic condition. Applied and Environmental Microbiology, 69(1): 562-567.

Đorđević, S., V. Mandić and D. Stanojević, 2016. The effect of bacterial inoculant on chemical composition and fermentation of alfalfa silage. Biotechnology in Animal Husbandry, 32(4): 413423.

Duncan, D., 1955. Multiple range and multiple F test. Biometrics, 11: 1.

Ebrahimi, M., M.A. Rajion, Y.M. Goh, A.Q. Sazili and J.T. Schonewille, 2013. Effect of linseed oil dietary supplementation on fatty acid composition and gene expression in adipose tissue of growing goats. BioMed Res. Int. 2013:1-11.

Ebrahimi, M., M.A. Rajion, Y.M. Goh, A.S. Farjam, A.Q. Sazili and J.T. Schonewille, 2014. The effects of adding lactic acid bacteria and cellulase in oil palm (Elais Guineensis jacq.) frond silages on fermentation quality, chemical composition and in vitro digestibility. Italian Journal of Animal Science, 13(3): 3358.

Elmenofy, E.K., M.I. Bassiouni, E.B. Belal, H.M.A. Gaafar, E.M. Abdel-Raouf and S.A. Mahmoud, 2011. Improving the nutritive value of ensiled green rice straw 1- Fermentation characteristics and chemical composition. J. Agric. Res. Kafer El-Sheikh Univ., 37(4): 571-582. 
Folch, J., M. Lees and G.H. Sloane Stanely, 1957. A simple method for the isolation and purification of total lipids from animal tissues. J. Biol. Chem., 226: 497-509.

Horrocks, R.D. and J.F. Vallentine, 1999. Harvested Forages. Academic Press, London, UK.

IBM SPSS Statistics, 2020. Statistical package for the social sciences, Release 27, SPSS INC, Chicago, USA

Jalč, D., A. Lauková, M. Simonová, Z. Váradyová and P. Homolka, 2009. The use of bacterial inoculants for grass silage: their effects on nutrient composition and fermentation parameters in grass silages. Czech J. Anim. Sci., 54: 84-91.

Jeranyama, P. and A.D. Garcia, 2004. Understanding Relative Feed Value (RFV) and Relative Forage Quality (RFQ). College of Agriculture \& Biological Sciences / South Dakota State University / USDA. Extension Extra. Paper 352.

Joo, Y.H., D.H. Kim, Dimas H.V. Paradhipta, H.J. Lee, S.M. Amanullah, S.B. Kim, J.S. Chang and S.C. Kim, 2018. Effect of microbial inoculants on fermentation quality and aerobic stability of sweet potato vine silage. Asian-Australasian J. Anim. Sci., 31(12): 1897-1902.

Kenilworth and Warwickshire, 2012. Silage Additives. Dairy Co. Agriculture and Horticulture Development Board, Stoneleigh Park.

Khota, W., S. Pholsen, D. Higgs and Y. Cai, 2017. Fermentation quality and in vitro methane production of sorghum silage prepared with cellulase and lactic acid bacteria. Asian-Australasian J. Anim. Sc., 30(11): 1568-1574.

Kim, H.S., O.K. Han, S.C. Kim, M.J. Kim and Y.S. Kwak, 2017. Screening and investigation Lactobacillus spp. to improve Secale cereale silage quality. Anim. Sci. J., 88: 15381546.

Marciňáková, M., A. Lauková, M. Simonová, V. Strompfová, B. Koréneková and P. Nad', 2008. A new probiotic and bacteriocin-producing strain of Enterococcus faecium EF9296 and its use in grass ensiling. Czech J. Anim. Sci., 53(8): 336-345.

Marciňáková, M., M. Simonová and A. Lauková, 2004. Probiotic properties of Enterococcus faecium EF9296 strain isolated from silage. Acta Veterinaria Brno, 73: 513-519.

McDonald, P., A.R. Henderson and S.J.E. Heron, 1991. The Biochemistry of Silage. 2nd ed. Chalcombe Publications, Marlow, UK.

Muck, R.E. and L. Kung, 1997. Effect of silage additives on ensiling, in Proceeding of the Silage: Field to feed Bunk, North American Conference, no. NRAES-99: 187-199.

NRC, 2007. Nutrient requirements of small ruminants: sheep, goats, cervids and new world camelids. Press, Washington, USA.

Pahlow, G., R.E. Muck and F. Driehuis, 2003. Microbiology of ensiling. Silage science and technology. Madison: American Society of Agronomy, Crop Science Society of America. Soil Science Society of America, 31-93.

Pholsen, S., W. Khota, H. Pang, D. Higgs and Y. Cai, 2016. Characterization and application of lactic acid bacteria for tropical silage preparation. Anim. Sci. J., 87: 1202-11.

Rajion, M., J. McLean and R. Cahill, 1985. Essential fatty acids in the fetal and newborn lamb. Aust. J. Biol. Sci., 38: 33-40

Rooke, F.M., F.M. Maya, J.A. Arnold and D.G. Armstrong, 1988. The chemical composition and nutritive value of grass silages prepred with no additives or either Lactobacillus plantarum of formic acid, Grass and Forage Sci., 43: 87-95.

Saarisalo, E., E. Skytaa, A. Haikara, T. Jalava and S. Jaakkola, 2007. Screening and selection of lactic acid bacteria strains suitable for ensiling grass. Journal of Applied Microbiology, 102: 327-336.

Sánchez, D.J.I., C.J.S. Serrato, S.D.G. Reta, M.E. Ochoa and G.A. Reyes, 2014. Assessment of ensilability and chemical composition of canola and alfalfa forages with or without microbial inoculation. Indian Journal of Agricultural Research, 48(6): 421-428.

Schmidt, R., W. Hu, J. Mills and L. Kung, 2009. The development of lactic acid bacteria and Lactobacillus buchnery and their effects on the fermentation of alfalfa silage. Journal of Dairy Science, 92: 5005-5010.

Seglar, B., 2003. Fermentation analysis and silage quality testing. Proceedings of the Minnesota Dairy Health Conference, College of Veterinary Medicine, University of Minnesota, 29 May, Minnesota, 119-136. 
Shaver, R.D., 2003. Practical application of new forage quality tests. Proceedings of the 6th Western Dairy Management Conference, Reno, USA. p. 22-25.

Stewart, W.M., 2011. Plant Nutrition Today. From Scientific Staff of the International Plant Nutrition Institute (IPNI), Norcross, Georgia.

Stoškus, R., J. Jatkauskas, V. Vrotniakienè and V. Juozaitienè, 2019. The effect of mixed bacterial inoculant on the microbial population and aerobic stability of lucerne and maize balage. Journal of Animal and Feed Sciences, 28: 383-391.

Van Soest, P.J., J.B. Robertson and B.A. Lewis, 1991. Methods for dietary fiber, neutral detergent fiber and nonstarch polysaccharides in relation to animal nutrition. J. Dairy Sci., 74: 3583-3597.

Yitbarek, M.B. Yitbarek and B. Tamir, 2014. Silage Additives: Review. Open Journal of Applied Sciences, 4: 258-274.

Zahiroddini, H., J. Baah, W. Absalom and T.A. McAllister, 2004. Effect of an inoculant and hydrolytic enzymes on fermentation and nutritive value of whole crop barley silage. Anim. Feed Sci. Technol., 117: 317-330.

Zhang, T., L. Li, X. Wang, Z. Zeng, Y. Hu and Z. Cui, 2009. Effects of Lactobacillus buchneri and Lactobacillus plantarum on fermentation, aerobic stability, bacteria diversity and ruminal degradability of alfalfa silage. World Journal of Microbiology and Biotechnology, 25: 965-971. 